Instructions for authors, subscriptions and further details:

http://redimat.hipatiapress.com

\title{
Uncovering the Relation between CK and PCK: An Investigation of Preservice Elementary Mathematics Teachers' Algebra Teaching Knowledge
}

Mustafa Güler ${ }^{1}$, Derya Çelik ${ }^{1}$

1) Karadeniz Technical University. Turkey

Date of publication: June $24^{\text {th }}, 2018$

Edition period: June 2018-October 2018

To cite this article: Güler, M., \& Çelik, D. (2018). Uncovering the relation between CK and PCK: An investigation of preservice elementary mathematics teachers' algebra teaching knowledge. REDIMAT - Journal of Research in Mathematics Education, 7(2), 162-194. doi:

10.4471/redimat.2018.2575

To link this article: http://dx.doi.org/10.4471/redimat.2018.2575

\section{PLEASE SCROLL DOWN FOR ARTICLE}

The terms and conditions of use are related to the Open Journal System and to Creative Commons Attribution License (CCAL). 
REDIMAT, Vol. 7 No. 2 Junio 2018 pp. 162-194

\section{Uncovering the Relation between CK and PCK: An Investigation of Preservice Elementary Mathematics Teachers' Algebra Teaching Knowledge}

Mustafa Güler

Karadeniz Technical University
Derya Çelik

Karadeniz Technical University

(Received: 20 February 2017; Accepted: 18 April 2018;Published: 24 June 2018)

\section{Abstract}

This article discuss the algebra teaching knowledge of preservice elementary mathematics teachers in the context of CK and PCK as well as the relationship between them. The study was conducted with 101 preservice teachers sampled from a state university in Turkey. Rasch analysis was used to interpret the data. The results revealed that preservice teachers performed at mid-level for both CK and PCK tests. It was also found that there was a significant correlation between the CK and PCK test scores. Weaknesses of the preservice teachers in terms of knowledge of the learner component of PCK, in comparison with presentation of content, were identified.

Keywords: Algebra teaching knowledge, content knowledge, pedagogical content knowledge, measuring teaching knowledge

2018 Hipatia Press

ISSN: 2014-3621

DOI: $10.4471 /$ redimat.2018.2575
Hipatia Press

www.hipatiapress.com

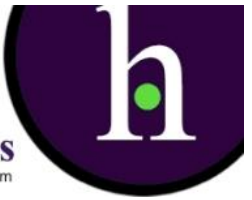




\section{Descubriendo la Relación entre CK y PCK: Un Estudio sobre el Conocimiento de la Enseñanza del Álgebra para Futuros Maestros/as}

Mustafa Güler

Karadeniz Technical University
Derya Çelik

Karadeniz Technical University

(Recibido: 20 Febrero 2017; Aceptado: 18 Abril 2018;Publicado: 24 Junio 2018)

\section{Resumen}

Este estudio discute el conocimiento de la enseñanza del álgebra de maestros de matemáticas elementales en el contexto de CK y PCK, así como la relación entre ellos. El estudio se llevó a cabo con 101 futuros/as maestros/as, tomados de la universidad estatal de Turquía. Se utilizó el análisis de Rash para interpretar los datos. Los resultados revelaron que los maestros/as en formación se desempeñan en el nivel medio para las pruebas de CK y PCK. También se encontró que había una correlación significativa entre la puntuación de las pruebas CK y PCK. Se identificaron las debilidades de los futuros docentes en cuanto al conocimiento del del contenido y de los alumnos en el modelo PCK, en comparación con el componente "presentación del contenido."

Palabras clave: Conocimiento de la enseñanza del álgebra, CK, PCK, medición del conocimiento de la enseñanza 
$\mathbf{R}$

apid accumulation of knowledge in society and technological advances require an altering of educational curricula. Teachers, as the primary implementers of teaching programs, play a leading role in the success of a curriculum, even if the curriculum has been perfectly prepared. In this regard, teachers' decisions and applications are fundamentally based on the knowledge they possess. However, the formerly widely-held notion that "the one who knows teaches" is no longer fully supported, with the types of professional knowledge that a teacher should possess being redefined (An, Kulm \& Wu, 2004; Baki, 2012a; Ball, Thames \& Phelps, 2008; Grossman, 1990; Shulman, 1986).

Shulman (1986), in one of the early works in this area, emphasized 3 fundamental components of knowledge that a teacher should possess. These components include content knowledge, pedagogical content knowledge and curriculum knowledge. Shulman (1987) described the components of content knowledge and pedagogical content knowledge as separate, but related. In this sense, content knowledge is composed of both content knowledge and pedagogical knowledge and is necessary for effective instruction. This type of knowledge represents the capacity for carrying out special representations, examples and demonstrations that allow students to comprehend the given subject matter. In other words, it refers to how subject matter is taught. It concerns anticipating the concepts that may be difficult for students to learn, as well as determining and putting into practice appropriate strategies, techniques and methods for overcoming these difficulties. This classification, which was made by Shulman approximately 30 years ago, has been taken as a reference by various researchers among knowledge categories for specific disciplines.

For instance, numerous scholars (e.g., Baki, 2012a; Ball, Thames \& Phelps, 2008; Fennema \& Franke, 1992; Grossman, 1990) have defined the concept of mathematics teaching knowledge over time. Ball et al. (2008), for example, describe mathematical knowledge for teaching school mathematics as the ability to use a technique or a method and to determine the most appropriate way to present content, as well as possessing the relevant mathematical content knowledge. What is common for all the above-referenced studies is their emphasis on content knowledge and pedagogical content knowledge as the two most prominent knowledge components a teacher should have. 
Defining teaching knowledge and its sub-components is important in terms of forming a basis for evaluating the knowledge of teachers, which is an important process due to its impact on student learning. Studies in this regard may be significant in terms of providing information about the efficiency of in-service and preservice educational activities. However, a review of the related literature reveals that many the existing studies relating teacher knowledge have been conducted primarily on a micro level; i.e., they have mainly focused on a single concept and the teaching of that concept (e.g. Chick \& Harris, 2007; Iş1ksal, 2006; Kazima, Pillay \& Adler, 2008; Stump, 1999; Şahin, Gökkurt, \& Soylu, 2016; Taylan, da Ponte, 2016). In recent years, there has been increasing number of studies examining teacher knowledge in a particular subject area (Danisman \& Tanisli, 2017; Ferrini-Mundy, Burill, Floden \& Sandow, 2003; Li, 2007; McCrory, Floden, Ferrini-Mundy, Reckase \& Senk, 2012); algebra among them.

The teaching and learning of school algebra has been emphasized in recent years in Turkey due to its crucial role as a foundation for secondary and university level mathematics. When considering mathematics as a generalization process (NCTM, 2000), one can refer algebra as the language of generalization (Usiskin, 1988). Thus, educators have defined algebra as one of the three central learning fields of school mathematics. In addition to its status as basis for more advanced mathematics, algebra is known for improving mathematical thinking and providing opportunities to analyze mathematical issues, and therefore is an important component of the school curriculum (Moses, 1995; NCTM, 2000). With these considerations in mind, the teaching of algebra, as well as learning, becomes an important concern addition to learning of it.

However, although the crucial role of algebra in school mathematics, educational studies in the national perspective revealed low student achievement in algebra learning field (e.g. Çelik \& Güneş, 2013; Yenilmez \& Avcu, 2009). Similarly, low algebra performance of Turkish students in international exams such as TIMSS (Bütüner \& Güler, 2017) and PISA (An11, Özer Özkan, \& Demir, 2015) has shifted to focus on the studies related to algebra teaching. In other words, investigating algebra teaching knowledge of in service and preservice mathematics teachers in the dimensions of content knowledge and pedagogical knowledge may be a variable to predict the current or future students' academic achievements. In 
this regard, algebra content knowledge (ACK) and algebra pedagogical content knowledge (APCK) terms come to the forefront. While ACK refers mostly existing objectives in the curriculum and the mathematical facts behind those objectives, APCK is required to simplify these facts as well as knowing the nature of concept, being aware of the misconceptions that students commonly surface, shaping the manner in which teachers teach, making it understandable for students and so on (Ferrini-Mundy, McCrory \& Senk, 2006). The components of ACK and APCK are detailed in theoretical framework.

The present study takes this into account by focusing on algebra as a subject field while sampling the content knowledge and pedagogical content knowledge of future teachers.

\section{Theoretical Framework}

Various studies have been conducted to define the knowledge types that a mathematics teacher should possess (Baki, 2012a; Ball, Thames \& Phelps, 2008; Fennema \& Franke, 1992; Grossman, 1990). While some of those studies differ in terms of their definition of context knowledge (Grossman, 1990) or beliefs (Fennema \& Franke, 1992) as components of mathematics teaching knowledge, it has been generally agreed that content knowledge and pedagogical content knowledge are the two most important elements of mathematics teaching knowledge. In this respect, content knowledge can be broadly defined as awareness of core mathematical concepts and operations and the relationship between them. Pedagogical content knowledge, on the other hand, includes the knowledge and methods necessary to make mathematics concepts understandable for students. Pedagogical content knowledge, in turn, is made up of components such as knowledge of the learner (student), special teaching methods, methods of planning and presenting content, and approaches for measurement and assessment (Baki, 2012a; Ball, Thames \& Phelps, 2008; Grossman, 1990).

Within the scope of this study, the subcomponents of knowledge of the learner and presentation of the content are emphasized due to their central importance in the teaching-learning environment. Knowledge of learners basically calls for understanding students' thinking and learning difficulties, as well as awareness of their prior knowledge and possible misconceptions 
(Baki \& Baki, 2010; Baki, 2010; 2012a; Ball, Thames \& Phelps, 2008; Marks, 1990; Shulman, 1986; 1987). Presentation of content, on the other hand, involves a multilateral structure including the examples, presentations and analogies used to render content meaningful for students (FerriniMundy, McCrory \& Senk, 2006).

While the existing studies aiming to define mathematics teaching knowledge are important in terms of offering a general framework, they are superficial with respect to defining teaching knowledge as it relates to the various subjects and concepts in mathematics (Li, 2007). The content that requires investigation in terms of algebra, data and geometry knowledge and skills differs in substantial ways. Therefore, different models are needed that are specific to the subject, reflecting its core content, base knowledge and skills. With this in mind, the researchers elected to apply conceptual framework developed by Ferrini-Mundy et al. (2003), as it focuses particularly on the teaching knowledge that is necessary for teaching algebra-related topics. The knowledge types that mathematic teachers should possess for effective algebra teaching are described within this framework, as illustrated in Figure 1.

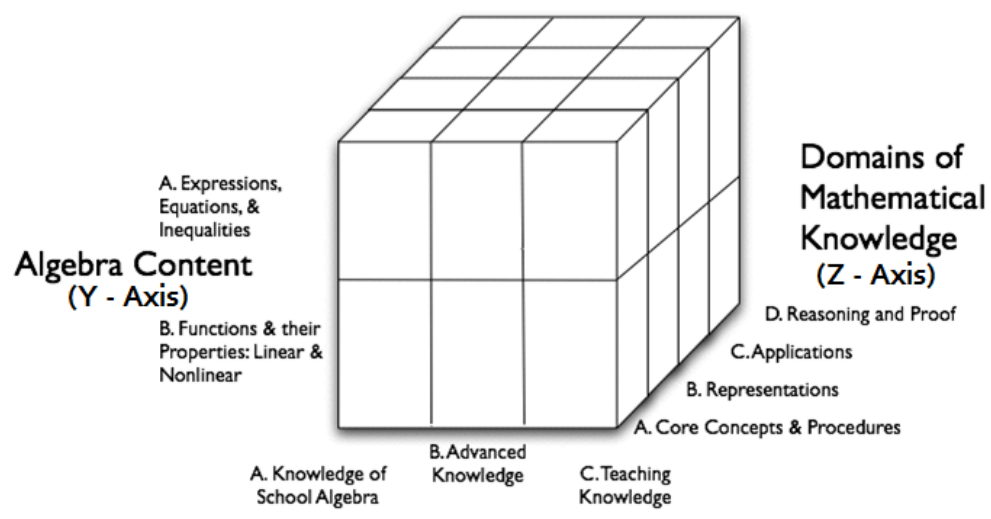

Algebra Knowledge for Teaching

(X - Axis)

Figure 1. Conceptual framework for evaluating algebra teaching knowledge (Ferrini-Mundy, Floden, McCrory, Senk \& Reckase, 2005) 
Figure 1 illustrates the requisite knowledge for teaching school algebra within a 3-dimensional structure, comprising algebra knowledge for teaching, algebra content, and the domains of mathematical knowledge. Algebra knowledge for teaching, which is represented by the X-axis, is composed of three subdivisions: school algebra, advanced algebra and teaching knowledge. In this regard, school algebra reflects the attainments of the corresponding curriculum and its pertinent concepts. Advanced algebra, on the other hand, represents secondary school and university level algebra; these form a theoretical base for the conceptual understanding of school algebra. While these two components are primarily related to content, the third component, teaching knowledge, prioritizes instructional activities (Ferrini-Mundy, McCrory \& Senk, 2006). In a general sense, teaching knowledge includes a variety of competences that fall within the category of pedagogical content knowledge, including awareness of the reasons that learning a particular concept is difficult; anticipating student misconceptions and incorrect conceptions; and presentation of the mathematical content required to reach instructional attainments (FerriniMundy, McCrory \& Senk, 2006). Therefore, it can be said that the teaching knowledge component defined in this framework coincides with the concept of pedagogical of content knowledge described in other theoretical studies.

In the current investigation, algebra content (corresponding to the $\mathrm{Z}$ axis) and the domains of mathematical knowledge (the $\mathrm{Y}$ axis) of FerriniMundy et al.'s (2005) conceptual framework and outlined in Figure 1 were used as originally designed. However, the algebra knowledge for teaching (corresponding to the $\mathrm{X}$ axis) was restricted and adapted to comprise advanced algebra knowledge, knowledge of learners, and presentation of content components. This adapted framework is illustrated in Figure 2. 


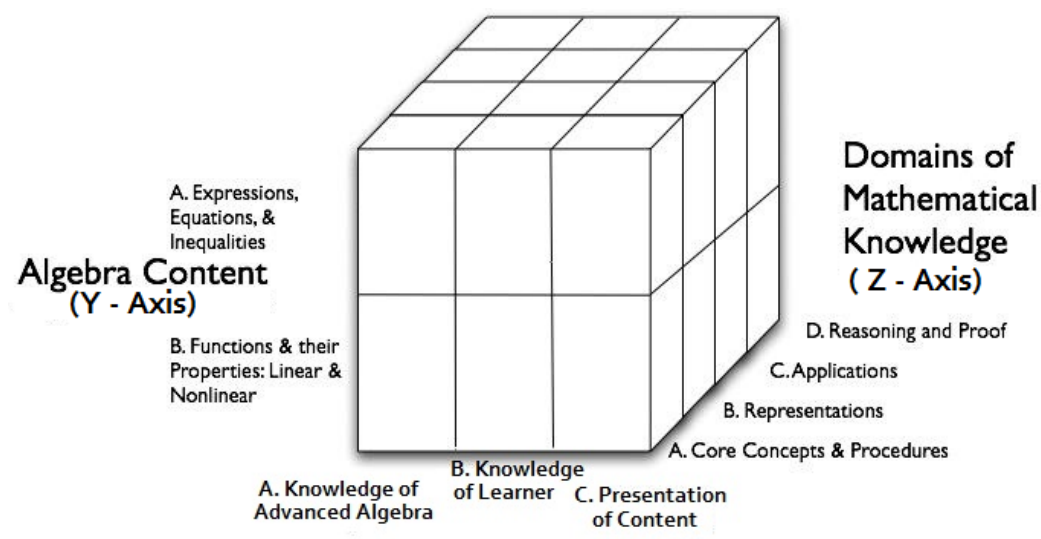

Algebra Knowledge for Teaching (X - Axis)

Figure 2. Revised framework for evaluating algebra teaching knowledge

The conceptual framework introduced by Ferrini-Mundy et al. (2005) allows the identification of algebra teaching knowledge of teachers/teacher candidates in terms of preparing qualitatively and quantitatively sufficient questions for each dimension and its components. In this study, we deepened PCK into two dimensions, as they have been frequently mentioned in the literature (Ball, Thames \& Phelps, 2008; Shulman, 1986). Questions were prepared to address each of the cubes shown in Figure 2. On the other hand, the content knowledge dimension was restricted to the knowledge of advanced algebra. This restriction can also be seen in other studies (e.g. Li, 2007) that were produced from KAT project.

\section{Aim of the Study}

This study aims to investigate the algebra teaching knowledge of senior preservice elementary mathematics teachers at the completion of their teacher training program. In accordance with this aim, the authors focused on the following sub-aims:

- To determine the algebra content knowledge of preservice elementary mathematics teachers, 
168 Güler \& Çelik - CK vs. PCK en la Enseñanza del Álgebra

- To determine preservice elementary mathematics teachers' knowledge of learner and presentation of content as components of their pedagogical content knowledge.

- To investigate whether a relationship exists between content knowledge and pedagogical content knowledge.

\section{Method}

This study aims to investigate the algebra teaching knowledge of senior preservice elementary mathematics teachers at the completion of their teacher training program. In accordance with this aim, the authors focused on the following sub-aims:

- To determine the algebra content knowledge of preservice elementary mathematics teachers,

- To determine preservice elementary mathematics teachers' knowledge of learner and presentation of content as components of their pedagogical content knowledge.

- To investigate whether a relationship exists between content knowledge and pedagogical content knowledge.

\section{Participants}

The study was performed with 101 preservice teachers in their final semester of an Elementary School Mathematics Education department in a public university in the 2012-2013 academic year. In Turkey, where the study took place, teacher training programs are carried out according to a standardized curriculum overseen by the Turkish Council of Higher Education (YÖK). Thus, the participants had the same learning experience as students enrolled in similar programs in other universities (for a list of the courses included in the program, see YÖK, 2016).

\section{Data Collection Tools}

Algebra Content Knowledge (ACK) and Algebra Pedagogical Content Knowledge (APCK) tests developed by researchers were used as data 
collection tools. The conceptual framework in Figure 2 was utilized in the development process. For the content knowledge and pedagogical content knowledge tests, five main concepts (algebraic expressions, patterns, equality and equations, inequalities and functions) relating to algebra content were targeted with reference with the curriculum. The item pool for the tests was assembled with the help of projects such as TEDS-M and KAT, as well as studies in literature pertaining to student misconceptions and learning difficulties in algebra (Even, 1993; Grossman, 1995; Haciomeroglu, 2005; Özmantar, Bingölbali \& Akkoç, 2008; Selden \& Selden, 2003).

Five doctorate level postgraduate students were asked to answer and evaluate the items to test their completeness, clarity and correctness. Afterward, as the first step of a pilot study, the tests were revised according to the feedback of the evaluators and then applied to 30 students who were in their 3rd year of study. This pilot study provided insight into the comprehensibleness of the items and helped with the determination of probable responses and the duration of the application. Based on the probable responses, a draft rubric was developed for analyzing the responses of the open-ended questions.

In the next step, the items were compiled in a form (see Appendix 1) and submitted to five academics with degrees in mathematics education. These experts were requested to state the extent to which the items reflected the conceptual framework shown in Figure 2. This process was performed to increase the content validity of the tests. Furthermore, in consideration of the opinions of the experts, four items from the APCK and 1 item from the ACK test were excluded. In the second step, to determine the validity and reliability of the test, the ACK (24 items) and APCK (23 items) were applied with 614 th year (senior) pre-service teachers within a 120-minute application period. The test booklets were prepared as Group A and Group B to prevent students from influencing each other's answers. The second pilot was important in terms of finalizing the rubrics to be used for evaluating responses to the open-ended questions and for anticipating the test statistics.

The item and test statistics were determined based on the Rash model, which is one of the models of Latent Traits Theory (LTT). According to LTT, there is a relationship between the skills of individuals in a particular field and their responses to question items concerning that field; this 
relationship can be expressed in a mathematical sense (Berberoğlu, 1998; Doğan, 2002). Since skill scores (described in Logits) can be obtained independently from tests applied to individuals-namely, independent from a group (Berberoğlu, 1998; Wright, 1977), they are more fundamental in nature than both real and observed scores in LTT (given that real and observed scores in classical test theory are dependent on the test). In other words, an individual taking two different examinations targeting the same trait in a close time interval can score lower on the more difficult of the two, and higher on the easier. However, the skill of the individual in relation to the evaluated trait remains constant (Hambleton \& Jones, 1993). Numerous projects aiming to evaluate the teaching knowledge of preservice teachers, such as MT-21 and TEDS-M (Schmidt, et al., 2007; Tatto, et al., 2008), as well as studies evaluating the mathematics performance of students, have applied this theory and model (e.g., Izard, Haines, Crouch, Houston \& Neil 2003; Koparan 2012; Misailidou \& Williams 2003; Watson, Kelly \& Izard 2004). In addition, it is stated in the literature that the Rasch model is an appropriate and easy means for interpretation in developing and evaluating tests, including those consisting of open ended items where participants receive partial credit based on the rate of correctness of their answers (Blömeke, Houang \& Suhl, 2011; Koparan, 2012; Warburton, 2013). Backed by these reasons, this model is preferred in developing ACK and APCK tests composed of both multiple choice and open ended questions.

The responses to the test items were scored as 0 or 1 for multiple choice and short answer items, and a maximum of 2 points were given for open ended items. The raw scores obtained from each pre-service teacher were analyzed with WINSTEPS 3.72, which complies with the Rasch model. First, item-model fitness was tested to provide fit validity. Any abnormalities represented a lack of fit between the items and the model (Aziz et al., 2016). In the literature, it is reported that input/output values should fall between 0.5 and 1.7 for item-model fitness (Bond \& Fox, 2007).

According to Wolfe and Smith (2007a, 2007b), these values are also indicators of construct validity. This analysis showed that one item in the ACK test, and 3 items in the APCK test, had insufficient fitting values. After concluding that removal of these items would not affect the content validity adversely, these items were excluded from the respective tests. The final ACK test consisted of 23 items, and the final APCK test had 20 items. 
Reliability analysis (see Appendix 2) revealed that individual reliability, which presents a close value to the general test reliability coefficient, was between .80 and .82 for the ACK and between .81 and .83 for the APCK. The reliability coefficient Cronbach's Alpha for both tests was calculated as .80. Since the value of Cronbach's alpha was greater than .70, the reliability of the tests falls within the acceptable range (Santos, 1999). (For sample questions, see Appendix 3).

\section{Analysis of Data}

The responses given by the participants to the ACK and APCK tests were scored and recorded in two Excel files. The rubrics that had been developed for the purpose were used in the evaluation of the open-ended questions. Table 1 illustrates the scoring rubric for the $3^{\text {rd }}$ item of the ACK test.

Table 1.

Scoring rubric used for the $3^{\text {rd }}$ item of the ACK test.

3. Prove correctness of the following proposition:

"If the graphs of linear functions $\mathrm{f}(\mathrm{x})=\mathrm{ax}+\mathrm{b}$ and $\mathrm{g}(\mathrm{x})=\mathrm{cx}+\mathrm{d}$ intersect at a point $P$ on the $x$-axis, the graph of their sum function $(\mathrm{f}+\mathrm{g})(\mathrm{x})$ must also pass through P."

(Adopted from TEDS-M Project, See Tatto et al., 2008)

\begin{tabular}{ll}
\hline 2 points & $\begin{array}{l}\text { Responses make mathematically correct } \\
\text { inferences and complete the proof }\end{array}$ \\
\hline 1 point & $\begin{array}{l}\text { Responses make mathematically correct } \\
\text { inferences but cannot complete the proof }\end{array}$ \\
\hline points & $\begin{array}{l}\text { Blank responses, incorrect mathematical } \\
\text { statements, fully wrong inferences }\end{array}$ \\
\hline
\end{tabular}

The data were collected in Excel files and then transferred into WINSTEPS 3.72. An item-person map was then prepared for each test by converting the raw scores of the pre-service teachers into linear scores. This was done with the aim of visualizing the achievement state of the candidates. The skill levels of a person for a given trait varies between -3 and +3 logit, and a move from -3 towards +3 represents increasing individual skill level (Cepicka, 2007). In addition to item-person maps, it is 
also possible to form person-item maps. Item-person maps compare both the skills of the participants and the item difficulties on a single scale. Items having fewer than 0 linear points, i.e., items having a negative linear score in the item-person map, are referred to as hard items (Koparan, 2012). Finally, the correlation between APCK and ACK was determined using the Spearman-Brown analysis due to the data did not fulfill the requirement $(\rho>.05)$ of normality test.

\section{Findings}

In this section, the findings of the analyses of the ACK and APCK tests are presented. First, the ACK and APCK scores of the participants were converted to linear scores, and then student achievement and the ratio of the items to which they responded were compared.

Item-person and person-item maps were assembled based on the linear scores extracted from the data obtained from the ACK and analyses. The resulting item-person map is presented in Figure 3, and the person-item map is presented in Figure 4.

The Item - person map shown in Figure 3 reveals that 65 pre-service teachers out of 101 scored below the accepted achievement limit of 0 point for the ACK test. When the whole test is considered, it can be observed that most of the participants scored between -1 and +1 , and more than half of the participants falling into this interval scored between -1 and 0 . While $11 \mathrm{P}, 41 \mathrm{P}$ and $53 \mathrm{P}$ were the most successful participants, 51P, 40P and 75P were the least successful. To determine which items gave the participants difficulty -- in other words, the items that had a lower rate of response, the individual-item map shown in Figure 4 was used.

Item-person and person-item maps were assembled based on the linear scores extracted from the data obtained from the ACK and analyses. The resulting item-person map is presented in Figure 3, and the person-item map is presented in Figure 4.

The person - item map in Figure 4 reveals that the pre-service teachers had the greatest difficulty in a section of item 18 (item 18a) and item 4 . On the other hand, item 8 and item 15 respectively were the most easily answered items. The items with a linear point lower than 0 -- i.e., items that the preservice teachers had difficulty answering, were mainly accumulated in the knowledge component of "linear - non-linear functions and their properties". Furthermore, when the dimension; "domains of mathematical 
knowledge" was investigated, it was observed that the pre-service teachers had the greatest difficulty in items that fell into the "applications" knowledge component.
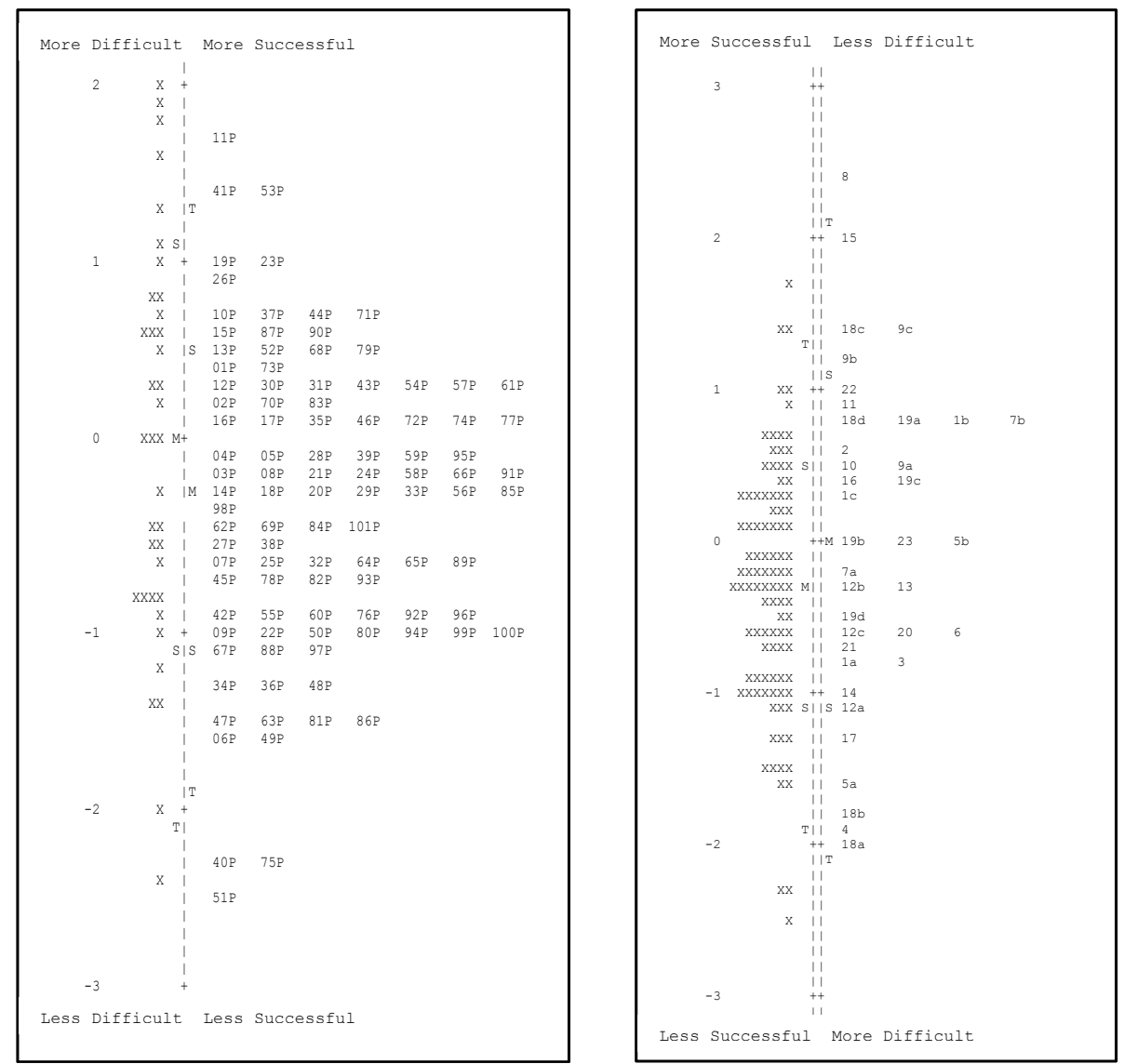

*P: Person (For example 27P represents $27^{\text {th }}$ person/participant)

Figure 3. Item - person map of ACK test Figure 4. Person - item map of ACK test

As for the ACK, item-person and person-item maps were assembled based on the linear scores extracted from the data obtained from the APCK 
and analyses. The resulting item-person map is presented in Figure 5, and the person-item map is presented in Figure 6.

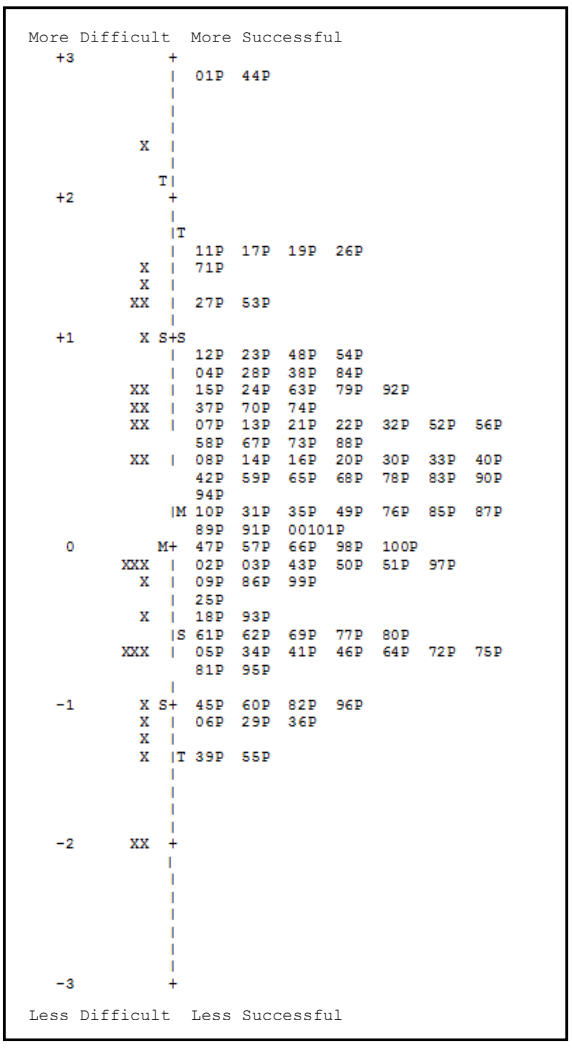

Figure 5. Item - person map of APCK test

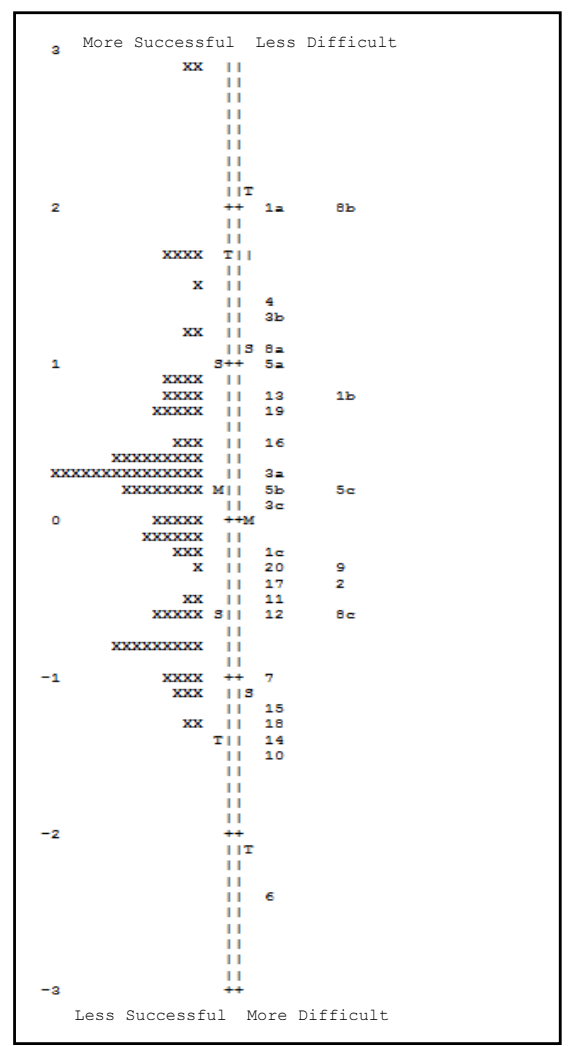

Figure 6. Person - item map of APCK test

Referring to the item-person map in Figure 5, participants 1 and 44 had the highest level of success on the APCK test, while 39P and 55P had the lowest. Furthermore, 47P, 57P, 66P, 98P and 100P performed at moderate achievement level. When all of the participants were considered out of 101 pre-service teachers, it can be seen that 61 of the pre-service teachers were successful, 5 were successful at a moderate level, and 35 pre-service 
teachers scored below the achievement limit of 0 . The scores of the majority of the successful pre-service teachers were between 0 and 1 ; and the pre-service teachers with low success were between 0 and -1 .

An examination of Figure 6, representing the person-item map, reveals that the items with which the pre-service teachers had the greatest difficulty were items 6 and 18. On the other hand, items 1a and 18b were the easiest. Evaluated in the algebra content dimension, the most difficult items for the pre-service teachers were related to "linear- non-linear functions and their properties" in the ACK test. However, in the domains of the mathematical knowledge dimension, quite different results were obtained. In this dimension, the items that presented the most difficulty clustered around the component of "core concepts and procedures". Furthermore, the "applications" component, with which the pre-service teachers had been the least successful in the ACK, was the item answered with the highest ratio for the APCK test. In examining the APCK test in the context of pedagogical content knowledge, it can be said that the pre-service teachers were more successful in answering items related to the presentation of content than items about the knowledge of learners. In other words, the success level of most of the pre-service teachers with respect to items pertaining to the knowledge of learners (31\%) was much lower than items about presentation of content (56\%).

For the sake of clarifying the issue and forming an overall picture in the context of algebra content and the domains of mathematical knowledge, the distribution of the ACK and APCK test items whose scores fell below 0 in the various components are illustrated in Figure 7 and Figure 8.

Figure 7 shows that pre-service teachers were successful on more than half of the items in the "algebraic expressions, equations and inequalities" component of the ACK and APCK tests. However, the opposite occurred in terms of the "Functions and their properties: Linear and nonlinear" component. Thus, it can be said that the pre-service teachers had greater difficulty with the items related to "linear and nonlinear functions and their properties" than the items concerning "algebraic expressions, equations and inequalities" on both tests. The performance of the pre-service teachers on the items related to the components of domains of mathematical knowledge are presented in Figure 8. 
176 Güler \& Çelik - CK vs. PCK en la Enseñanza del Álgebra

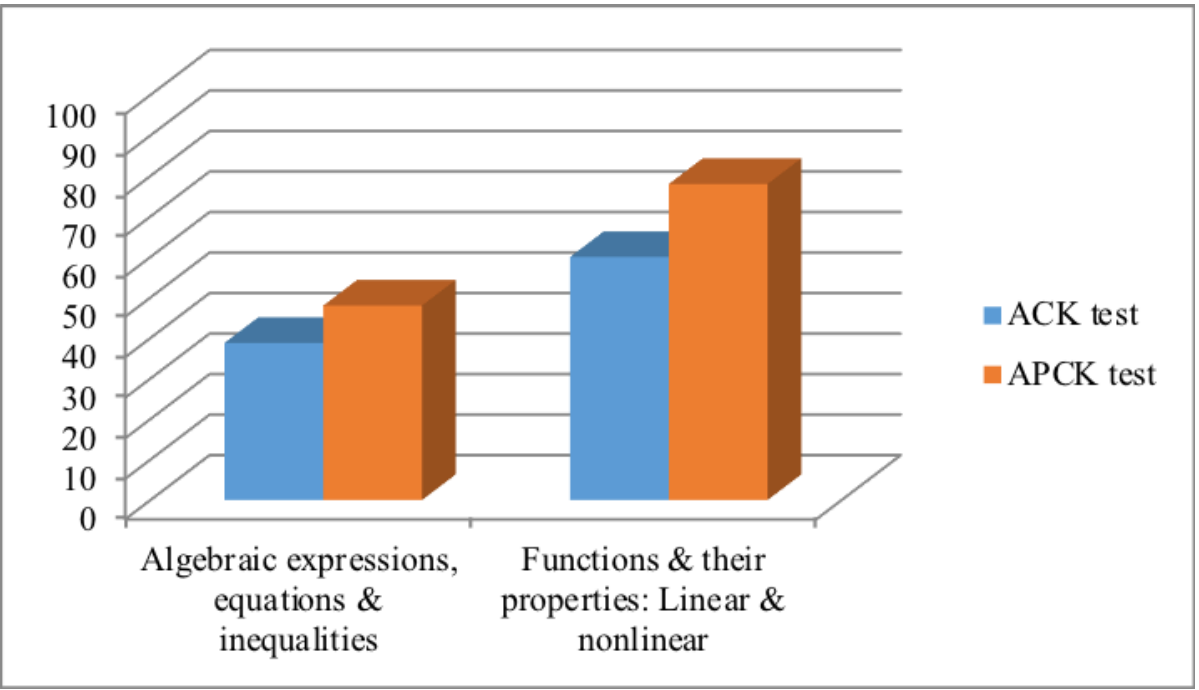

Figure 7. Rate of items falling below the level of zero in the components of algebra content

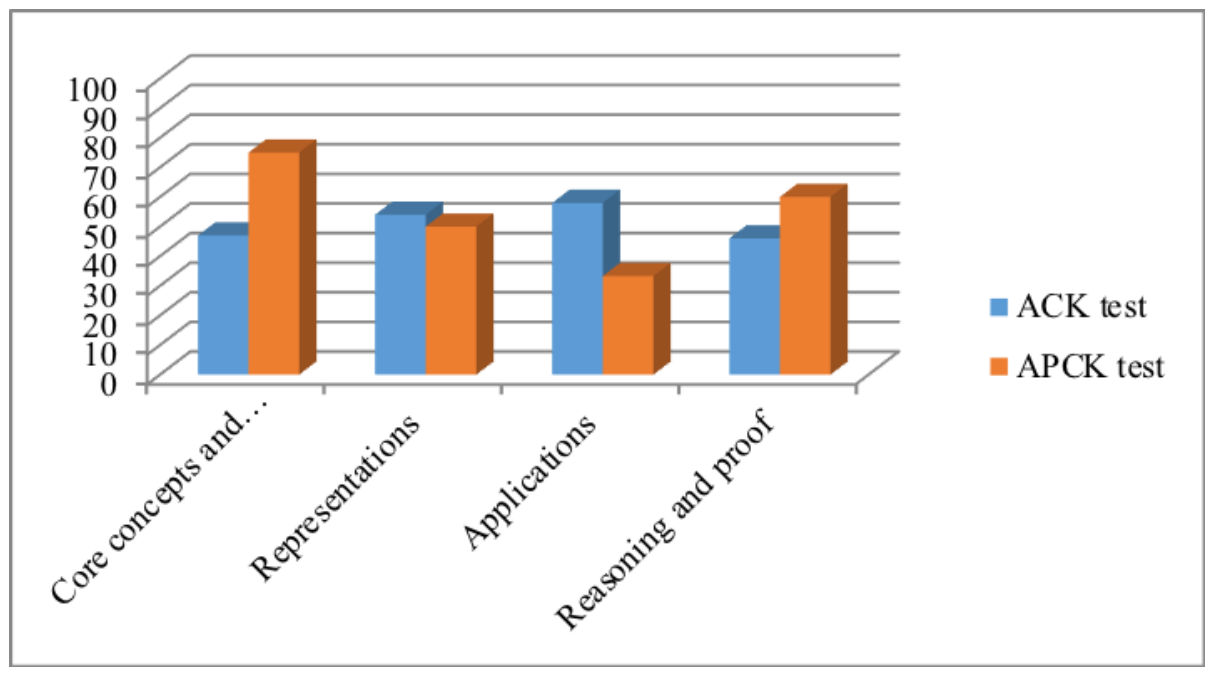

Figure 8. Rate of items falling below zero level in components of mathematical content 
Based on the data presented in Figure 8, it can be said that the preservice teachers exhibited a similar level of success for the component of "representations" on the ACK and APCK tests. However, it was apparent that their performance in the knowledge components such as "core concepts and procedures" and "applications" were quite different. While about the half of the pre-service teachers were not successful in answering the items in the "applications" component of the ACK test, approximately the same ratio fell into one-third on the APCK test. On the "core concepts and procedures" component, approximately one third of the pre-service teachers had difficulty in answering the items on the ACK test, more than two third of them could not answer these on the APCK test. The greatest level of success was seen in the items relating to the "fundamental concepts and procedures" and "reasoning and proof" components of the ACK test, as well as the "applications" and "representations" components of the APCK test.

Finally, the relationship between CK and PCK was determined with the Spearman correlation test. The summary of the test results is shown in Table 2.

Table 2.

Spearman Correlation between APCK and ACK

\begin{tabular}{llll}
\hline & & APCK & ACK \\
\hline \multirow{3}{*}{ APCK } & rho & 1.000 & $0.404^{* *}$ \\
& $\mathrm{p}$ & & 0.000 \\
& $\mathrm{n}$ & 101 & 101 \\
\cline { 2 - 2 } & rho & $0.404^{* *}$ & 1.000 \\
& $\mathrm{p}$ & 0.000 & \\
& $\mathrm{n}$ & 101 & 101 \\
\hline
\end{tabular}

**Correlation is significant at the .01 level

Table 2 indicates that there was a positive, moderate correlation between PCK and PCK of the participants (Spearman's $\rho=.404 ; p=.000$ ) as expected. In other words, this result indicates that students with high PCK scores had relatively high scores on the $\mathrm{CK}$, as well. 
178 Güler \& Çelik - CK vs. PCK en la Enseñanza del Álgebra

\section{Discussion and Conclusion}

In this study, which aimed to determine the algebra content knowledge (ACK) and pedagogical content knowledge (APCK) of pre-service mathematics teachers, an ACK and an APCK test were applied with 101 teacher candidates. A Rasch analysis performed on the results revealed that 36 of the pre-service teachers on the ACK test, and 61 pre-service teachers on the APCK test, scored above the reference success limit level zero. The average linear scores of the pre-service teachers were calculated at -0.3 for ACK and at 0.17 for APCK. Although the average achievement levels of the pre-service teachers on the APCK was higher than on the ACK, it can be said that the achievement level for both tests was similar. When the item-person maps for both tests (Figure 3 and Figure 5) were examined, more than half of the items on the AFCK test and almost half of the items on the APCK had negative logit. In other words, the pre-service teachers had difficulties in answering nearly half of the questions. On the other hand, hypothesizing that there is a relation between content knowledge and pedagogical content knowledge (e.g. Ball et al., 2008; Ozden, 2008); this study has tested and presented evidences from a qualitative study. As a consequence, the results of the current study indicate a positive moderate correlation between APCK and ACK.

As a component of pedagogical content knowledge, knowledge of learners requires awareness of students' pre-knowledge, learning and misconceptions (Baki, 2012b; Ball, Thames \& Phelps, 2008; Carpenter, Fennema, Peterson \& Carey, 1988; Marks, 1990; Shulman, 1986; 1987). When meaningful learning is defined as learning by associating new information with existing knowledge, and thereby constructing new knowledge, awareness of the prior knowledge of learners is an important consideration for effective instruction (Baki, 2012b). In this respect, the present study showed that the majority of the pre-service teachers had difficulty in situations requiring knowledge of learners; as most of the APCK items that caused difficulty for the pre-service teachers were about determining the way students think. On the other hand, the pre-service teachers were more successful in the presentation of content component than that of knowledge of learners; yet, when the test was reconsidered as a whole it was determined that their achievement was not at an adequate level, and nearly half of the pre-service teachers failed on these items. Thus, 
enriching the content of the Special Instructional Methods course and teaching it for a longer duration may be considered beneficial both in terms of improving the professional attributions of pre-service teachers and in minimizing the adverse effects of lack of experience of beginner teachers.

Since teachers' mathematics knowledge affects the quality of instruction (Hill et al., 2008), content knowledge is also an important component of mathematics teaching knowledge. At the lower secondary level (middle school in the Turkish Educational System; grades 5 to 8), the topic of equations is important as foundation for advanced algebra. Mathematical content knowledge requires understanding both mathematical facts and the underlying reasons for these facts (Ball, 1988). Therefore, lower secondary level mathematics teachers should be aware not only of the concepts and attainments in the curriculum, but should also have higher secondary (e.g., lycée in the Turkish Educational System; grades 9-12) or sometimes university level mathematics knowledge related to the attainments in the curriculum. One such concept is that of functions, which are instructed implicitly at the lower secondary level. Dubinsky and Harel (1992) argued that functions are a "unique most important" concept for all classroom levels. The present study proved that the pre-service teachers had lack of knowledge about this important concept. This finding is similar to the results of the MT21, an international comparative project concerning the content knowledge of teachers from a wider perspective. In this case, it was determined that half of the participant countries had the lowest scores in the area of functions (Schmidt et al., 2007).

The weaknesses of the pre-service teachers' performance on the algebra content knowledge relating to linear and non-linear functions and their properties was also observed on the pedagogical content knowledge test. Furthermore, the response ratio of the pre-service teachers to the items in the related components of the pedagogical content knowledge test was lower than the field knowledge test (see Figure 7). The result obtained here can be interpreted as weakness in concept knowledge towards content knowledge, an important component of mathematics teaching knowledge that also affects pedagogical content knowledge. This relationship has also been described by Baki (2012a), Heaton (1992), and Hill et al. (2008).

The core concepts and procedures in the domains of mathematical knowledge include opinions and core concepts particular to specific fields, as well as their applied algorithms and mathematical procedures. These 
include counting, performing calculations, explaining expressions in algebraic form, solving equations, drawing function graphs, and rules or algorithms needed to perform these procedures (Li, 2007). Core algebraic concepts at the lower secondary level include patterns; variables; equations and inequalities; slope and linear functions and their graphs. In this study, one of the greatest level of achievement on the ACK test was related to the items concerning fundamental knowledge, as the researchers anticipated. The majority of the pre-service teachers were successful in responding to the items in this area. On the contrary, items related to core concepts and procedures on the APCK test led to the highest rate of failure. In other words, while the pre-service teachers were successful in their responses to the items relating to core concepts and procedures, they generally failed in their responses to items concerning the teaching of these concepts in relation to students' understanding. This implies that content knowledge alone is not sufficient to teach the subject matter. It is recognized that this idea constitutes the conceptual framework for the theoretical studies defining the types of knowledge that teachers should have, as well as the studies differentiating content knowledge and mathematics teaching knowledge (Baki, 2012a; Ball, Thames \& Phelps, 2008; Ferrini-Mundy et al., 2003; Grossman, 1990; Shulman, 1986; 1987). Similar results were also obtained in the TEDS-M project, which investigated the competences of pre-service teachers in an international context. In that project, it was determined that the average level of content knowledge was lower than mathematical pedagogical content knowledge (Tatto et al., 2012). Accordingly, it may be considered that more precise handling of mathematical concepts in teacher training institutions will improve both the mathematics and mathematics teaching knowledge of future mathematics teachers.

With respect to mathematical representations, the skills of organizing mathematical concepts and procedures and inter-relating the concepts are required. In this respect, Ferrini-Mundy et al. (2005) determined algebraspecific representations to be graphs; algebra tiles; tables and variables; and oral explanations of the relationships among them. Numerous studies in this area have remarked that selection, application and transformation among these representations is important for increasing understanding of algebraic concepts (Baki, 2012a; Ferrini-Mundy et al., 2005; Ma, 1999; NCTM, 2000). Considering the findings of the present study, the pre-service 
teachers showed a moderate level of success on items in the representations component of both the ACK and APCK tests. In other words, nearly half of the pre-service teachers failed on these items on both tests. Weaknesses with respect to algebraic representations, which have been frequently reported in primary and secondary level students (Ç.1kla, 2004; Hadjidemetriou \& Williams, 2002), were also encountered in this study. Because transition among representations is accepted as a fundamental component of mathematical thinking (Çelik, 2007; DeMarois \& Tall, 1996; Thompson, 1994), and the transition process contributes to conceptual learning and problem solving (Heinze, Star \& Verschaffel, 2009; Iş1k, Kar, İpek \& Iş1k, 2012; Lesh ve Doerr, 2003), the mathematical and algebraic thinking at the primary and secondary school depends on teachers' effective use of transition among representations. Accordingly, teacher training institutions have a responsibility to ensure that teacher candidates have a solid foundation in this area.

Applications, another component of mathematical knowledge, emphasizes the contextual association of mathematics problems with nonalgebraic cases, with other algebra-related topics, or with daily life (Burill, Ferrini-Mundy, Senk \& Chazan, 2004; Ferrini-Mundy et al., 2005). In this study, the highest achievements on the APCK test were related to the area of applications. Because the school curriculum stresses teachers' use of real-life applications in supporting meaningful learning, this result can be perceived as positive. However, the pre-service teachers did not exhibit a similar achievement level on the ACK test, hardstand this was shown to be the most difficult component on the content knowledge test. Therefore, it is possible that the pedagogical content knowledge items given in a scenario belonging to the knowledge of learner component already included the expected association, and that this increased the success ratio for the APCK test. Another potential reason for the teachers' greater success in this regard is the fact that the questions on the APCK were by nature suitable for lower achievement levels.

Considering the ACK test, in addition to core concepts and procedures, the pre-service teachers were most successful in the mathematical knowledge domain of "reasoning and proof," such as giving examples and counterexamples for given cases; proving cases by indicating analogies or geometrical proofs; and applying various proof techniques by considering the axiomatic system and making persuasive explanations (Ferrini-Mundy 
et al., 2005). In this respect, it was initially hypothesized that the reasoning and proof items requiring a high level of cognitive performance would present an area of difficulty; however, the actual performance of the preservice teachers was contrary to this assumption. This result can be explained by the emphasis given to reasoning and proof during the candidates' undergraduate education and may be seen as a positive aspect of the teacher training curriculum. However, the lack of success in the other domains of mathematical knowledge, as well as the serious weaknesses concerning the teaching of fundamental concepts, necessitates reconsideration of the content of courses in the field.

From an overall perspective, the average APCK scores of the preservice teachers were higher than the ACK scores. However, the average scores for both tests were close to a median level and did not reflect their intended achievement level. Concerning the pre-service teachers' roles in preparing lower secondary school students for the lycée level, it can be asserted that their knowledge related to the fundamental (core) concepts (e.g., functions) may negatively impact the quality of instruction they are prepared to deliver. The results of the present study coincide both with projects such as the TEDS-M and MT21, as well as the results of the nationwide Teaching Content Knowledge Test $\left(\mathrm{ÖABT}^{1}\right)$. In fact, the average scores for the 2014, 2015 and 2016 mathematics teaching ÖABT examinations were calculated at 20.135, 19.803 and 17.105 out of 50 respectively (ÖSYM, 2014; 2015; 2016), which further supports the results of this study. Additionally, a national project conducted by Çelik et al. (2016) concluded that other universities in Turkey showed similar performance in the context of mathematics teaching knowledge. Because the same teacher training program is applied throughout the country in primary and secondary mathematics teaching programs, the results of this study may reflect the difficulties to be encountered in other universities.

\section{Limitations and Future Research}

Current study aimed to investigate the algebra teaching knowledge of mathematics teacher candidates in the context of content knowledge and pedagogical content knowledge. Although this study found a significant relation between CK and PCK there are considerable limitations and suggestions for future research. It was not scope of this paper to make 
generalization of this result to whole subject areas of mathematics; therefore it is not sufficient to make a general conclusion that CK and PCK are interrelated to each other. The results of this study have only implications for knowledge for teaching algebra. As a result, there is a need for further studies developing measurement tools to be used in other individual (or all) subject areas. On the other hand, the theoretical framework used in this study was designed to examine teaching knowledge in the subject of algebra. Future researchers are suggested to adapt the presented framework to include different subject areas. A further limitation of this study was that the research aimed to picture the current state of the future teachers. There is a need to investigate how teacher training programs affect teacher candidates' $\mathrm{CK}$ and PCK throughout their bachelor's programs. The current study is focused only on the senior student teachers. As such, latitudinal studies are recommended by the authors. As a final suggestion, new instructional approaches that have been proven to increase the $\mathrm{CK}$ and PCK components of teaching knowledge (e.g. Baki et al., 2016; Santagata \& Guarino, 2011) should be implemented in teacher training programs.

\section{Notes}

${ }^{1}$ This article is based on a master's thesis completed by the first author under the supervision of the second author.

2 ÖABT is Turkish National Teacher Examination held by the Student Selection and Evaluation Center of Turkey, an independence institute. The ÖABT is a precondition for teaching at state schools. Graduates who achieve sufficient scores in their fields are appointed to teaching positions by the Ministry of Education.

\section{References}

An, S., Kulm, G., \& Wu, Z. (2004) The pedagogical content knowledge of middle school, mathematics teacher in China and the U.S. Journal of Mathematics Teacher Education, 7, 145-172. Doi: 10.1023/B:JMTE.0000021943.35739.1c

Anı1, D., Özer Özkan, Y., \& Demir, E. (2015). PISA 2012 study national report. PISA Uluslararası Öğrenci Değerlendirme Programı. Ankara: İşkur Matbaacılık. 
184 Güler \& Çelik - CK vs. PCK en la Enseñanza del Álgebra

Aziz, J. A., Mohamad, M., Shah, P. M., \& Din, R. (2016). Differential item functioning in online learning instrument (EPFun). Creative Education, 7, 180-188. Doi: 10.4236/ce.2016.71018

Baki M., Baki A., Çelik D., Güler M., \& Sönmez N. (2016, August).

Improving prospective mathematics teachers' knowledge of student through lesson analysis. Proceedings of the 40th Conference of the International Group for the Psychology of Mathematics Education, Vol 2, pp. 51-58, Szeged: PME.

Baki, A. (2010). An evaluation of teacher training from undergraduate and postgraduate dimensions. Inonu University, Journal of the faculty of Education, 11(3), 15-31.

Baki, A. (2012a, June). Matematik öğretme bilgisi [Mathematics teaching knowledge] Congress of $10^{\text {th }}$ National Science and Mathematics Education. 27-30 June, Nigde University, Nigde.

Baki, A. (2012b, September). Matematik öğretme bilgisi [Mathematics teaching knowledge]. Symposium of $11^{\text {th }}$ Mathematicians Association, 19-21 September, Ondokuz Mayıs University, Samsun.

Baki, M., \& Baki, A. (2010). Experiences of Turkey in teacher training and teaching knowledge of mathematics teachers. Proceeding of 4th International Symposium of Policies and Issues on Teacher Education, pp. 225-232.

Ball, D. L., Thames, M. H., \& Phelps, G. (2008). Content knowledge for teaching: What makes it special? Journal of Teacher Education, 59(5), 389-407. Doi: 10.1177/0022487108324554

Ball, D.L. (1988). Knowledge and reasoning in mathematical pedagogy:

Examining what prospective teachers bring to teacher education. Unpublished doctoral dissertation, Michigan State University, East Lansing.

Ball, D. L., Bass, H., Lewis, J., Sleep, L., Suzuka, K., Babson, A., Jacobs, J., Kim, Y., Thames, M., \& Zopf, D. (2008). Designing and using problems to teach mathematical knowledge for teaching. National Council of Teachers of Mathematics Research Presession, Salt Lake City, UT.

Berberoğlu, G. (1998). Seçme amactyla kullanılan testlerde Rasch modelinin katklları. Yayımlanmamış doktora tezi (Unpublished doctoral dissertation). Hacettepe University, Institue of Social 
Sciences, Ankara. Retrieved January, 2014 from https://tez.yok.gov.tr/UlusalTezMerkezi.

Blömeke, S., Houang, R., \& Suhl, U. (2011). TEDS-M: Diagnosing teacher knowledge by applying multidimensional item response theory and multi-group models. IERI Monograph Series: Issues and Methodologies in Large-Scale Assessments. No. 4, pp. 109-126.

Bond, T.G., \& Fox, C. M. (2007). Applying the Rasch model: Fundamental measurement in the human sciences (2nd ed.) Mahwah, N.J.: Erlbaum.

Carpenter, T. P., Fennema, E., P. L. Peterson, P. L., \& Carey, D. A. (1988). Teachers' pedagogical content knowledge of student's problem solving in elementary arithmetic. Journal for Research in Mathematics Education, 19, 385-401. Doi: 10.2307/749173

Cepicka, L. (2007). Measuring psychomotor skills: Developing a scale to measure ball-handling skills using the Rasch measurement model. In Degregorio, R. (Eds) New developments in psychological testing (pp. 187-212). New York: Nova Science Publishers.

Chick, H. L., \& Harris, K. (2007). Pedagogical content knowledge and the use of examples for teaching ratio. Paper presented at conference of the Australian Association for Research in Education. 25 - 28 November, Fremantle, WA.

Çelik, D. (2007). The analytic overview of algebraic thinking skills of preservice teachers. (Unpublished doctoral dissertation). Karadeniz Technical University, Trabzon.

Çelik, D. \& Güneş, G. (2013). Different grade students' use and interpretation of literal symbols. Educational Sciences: Theory \& Practice, 13(2), 1168-1186.

Çelik, D., Birgin, O., Gürbüz, R., Güneş, G., Taşkın, D., ... Özmen, Z. M. (2016). A comparative investigation of the knowledge and beliefs of preservice elementary mathematics teachers. TUBITTAK Project: $113 \mathrm{~K} 805$.

Ç1kla, O. (2004). The effects of multiple representations based instruction on seventh grade students' algebra performance, attitude toward mathematics and representation preference. Unpublished doctoral dissertation, Middle East Technical University, Ankara.

DeMarois, P., \& Tall, D. O. (1996). Facets and layers of the function concept. Proceedings of PME 20, Valencia, 2, 297-304. 
186 Güler \& Çelik - CK vs. PCK en la Enseñanza del Álgebra

Doğan, N. (2002). Comparison of classical test theory and latent traits theory by samples. Unpublished Doctoral dissertation, Hacettepe University, Institute of social sciences, Ankara). Retrieved from: https://tez.yok.gov.tr/

Dubinsky, E., \& Harel, G. (1992). Forward. In G. Harel and E. Dubinsky (Eds.), The concept of function: aspects of epistemology and pedagogy, MAA Notes, Number 25 (pp. 7-9). Washington, DC: Mathematical Association of America.

Even, R. (1993). Subject-matter knowledge and pedagogical content knowledge: Prospective secondary teachers and the function concept. Journal for Research in Mathematics Education, 24(2), 94-116. Doi: $10.2307 / 749215$

Fennema, E., \& Franke, M. (1992). Teachers' knowledge and its impact. In D.A. Grouws (Eds.), Handbook of research on mathematics teaching and learning. New York: Macmillan Publishing.

Ferrini-Mundy, J., Burrill, G., Floden, R., \& Sandow, D. (2003). Teacher knowledge for teaching school algebra: Challenges in developing an analytical framework. Paper presented at the annual meeting of the American Educational Research Association, Chicago, IL.

Ferrini-Mundy, J., Floden, R., McCrory, R., Burrill, G., \& Sandow, D. (2005). A conceptual framework for knowledge for teaching school algebra. East Lansing, MI: Authors.

Ferrini-Mundy, J., McCrory, R., \& Senk, S. (2006). Knowledge of algebra for teaching: Framework, item development and pilot results.

Research symposium at the research pre-session of NCTM annual meeting. St. Louis, MO.

Floden, R. E., Ferrini-Mundy, J., McCrory, R., Senk, S. and Reckase, M. (2005). KAT item development matrix. Retrieved from: http://www.educ.msu.edu/kat/ adresinden 20 Kasim 2013 tarihinde edinilmiştir.

Grossman, P. L. (1990). The making of a teacher: Teacher knowledge and teacher education. New York: Teachers College Press.

Grossman, P. L. (1995). Teachers' knowledge. In L. W. Anderson (Ed.), International encyclopedia of teaching and teacher education (2nd ed., pp. 20-24). Tarrytown, NY: Pergamon.

Haciomeroglu, G. (2006). Prospective secondary teachers' subject matter knowledge and pedagogical content knowledge of the concept of 
function. (Unpublished doctoral dissertation) Florida State University, USA.

Hadjidemetriou, C. and Williams, J.S. (2002). Children's graphical conceptions. Research in Mathematics Education, 4, 69-87. Doi: 10.1080/14794800008520103

Heaton, R. M. (1992). Who is minding the mathematics content? A case study of a fifth-grade teacher. The Elementary School Journal, 93(2), $153-162$.

Heinze, A., Star J. R., \& Verschaffel, L. (2009). Flexible and adaptive use of strategies and representations in mathematics education. ZDM Mathematics Education, 41(5), 535-540. Doi: 10.1007/s11858-0090214-4

Hill H. C., Blunk M. L., Charalambous C. Y., Lewis J. M., Phelps G. C., Sleep L., \& Ball D. L. (2008). Mathematical knowledge for teaching and the mathematical quality of instruction: An exploratory study. Cognition and Instruction, 26(4), 430-511. Doi:

10.1080/07370000802177235

Işık, C., Kar, T., İpek, A. S., \& Işık, A. (2012). Difficulties encountered by pre-service classroom teachers in constructing stories about line graphs. International Online Journal of Educational Sciences, 4(3), 644-658.

Iş1ksal, M. (2006). A study on pre-service elementary mathematics teachers' subject matter knowledge and pedagogical content knowledge regarding the multiplication and division of fractions. Unpublished doctoral dissertation, Middle East Technical University, Ankara.

Izard, J., Haines, C., Crouch, R., Houston, S., \& Neill, N. (2003). Assessing the impact of the teaching of modelling: Some implications. In $\mathrm{S}$. Lamon, W. Parker, K. Houston (Eds.), Mathematical Modelling: A Way of Life. ICTMA 11 (pp. 165-177). Chichester: Horwood Publishing.

Kazima, M., Pillay, V., \& Adler, J. 2008. Mathematics for teaching: observations of two case studies. South African Journal of Education, 28, 283-299.

Koparan, T. (2012). The effect of project based learning approach on the statistical literacy levels and attitude towards statistics of student. 
188 Güler \& Çelik - CK vs. PCK en la Enseñanza del Álgebra

Unpublished doctoral dissertation. Karadeniz Technical University, Institue of Educational Sciences, Trabzon

Lesh, R. and Doerr, H. (2003). Foundations of a models and modeling perspective on mathematics teaching, learning, and problem solving. In R. Lesh \& H. Doerr (Eds.) Beyond constructivism (pp. 3-34). Hillsdale, NJ: Erlbaum.

Li, X. (2007). An investigation of secondary school algebra teachers' mathematical knowledge for teaching algebraic equation solving. (Unpublished doctoral dissertation). The University of Texas at Austin. Retrived from http://hdl.handle.net/2152/3337

Ma, L. (1999). Knowing and teaching elementary mathematics: Teachers' understanding of fundamental mathematics in China and the United States. Mahwah, N.J.: Lawrence Erlbaum Associates.

Mathematics Study Panel (2003). Mathematics proficiency for all students. Santa Monica CA: RAND.

Marks, R. (1990). Pedagogical content knowledge: From a mathematical case to a modified conception. Journal of Teacher Education, 41(3), 3-11. Doi: 10.1177/002248719004100302

McCrory, R., Floden, R., Ferrini-Mundy, J., Reckase, M. D., \& Senk, S, L. (2012). Knowledge of algebra for teaching: A framework of knowledge and practices. Journal for Research in Mathematics Education, 43(5), 584-614. Doi: 10.5951/jresematheduc.43.5.0584

McMillan, J. H., \& Schumacher, S. (2001). Research in education: A conceptual introduction (5th ed.). New York: Longman.

Ministry of National Education [MoNE] (2013). Ortaokul ögretim matematik dersi (5, 6, 7 ve 8. Siniflar) ögretim programı [Curriculum of elementary mathematics for $5^{\text {th }}, 6^{\text {th }}, 7^{\text {th }}$ and $8^{\text {th }}$ grades]. Ankara:

MEB Yayınları.

Misailidou, C., \& Williams, J. (2003). Diagnostic assessment of children's proportional reasoning. Journal of Mathematical Behaviour, 22, 335-368. Doi: 10.1016/S0732-3123(03)00025-7

Moses, R. (1995). Algebra, the new civil right. In C. B. Lacampagne, W. Blair, \& J. Kaput (Eds.), The algebra initiative colloquium (Vol. 2) (pp. 53-67). Washington, DC: U.S. Department of Education, Office of Educational Research and Improvement. 
National Council of Teachers of Mathematics [NCTM] (2000).

Professional standards for teaching mathematics. Reston, VA:

Author.

Ozden, M. (2008). The effect of content knowledge on pedagogical content

knowledge: The case of teaching phases of matters. Educational

Sciences: Theory and Practice, 8(2), 633-645.

Öğrenci Seçme \& Yerleştirme Merkezi [ÖSYM] (2014). 2014 Kamu

Personeli Seçme Sınavı A Grubu ve Öğretmenlik Sonuçları. [[Results of Teacher Selection Examination of 2014] Retrieved January, 2015 from http://dokuman.osym.gov.tr/pdfdokuman/2014/KPSS/OABTSORUY ANIT/KPSS-2014-OABTsayisal25072014.pdf

Öğrenci Seçme \& Yerleştirme Merkezi [ÖSYM] (2015). 2015 Kamu

Personeli Seçme Sınavı Öğretmenlik Sonuçları [Results of Teacher

Selection Examination of 2015] . Retrieved December, 2015 from

http://dokuman.osym.gov.tr/pdfdokuman/2015/KPSS/2015KPSS_SA YISABILGILER28082015.pdf

Öğrenci Seçme \& Yerleştirme Merkezi [ÖSYM] (2016). 2016 Kamu

Personeli Seçme Sınavı Öğretmenlik Sonuçları [Results of Teacher

Selection Examination of 2015] . Retrieved September, 2016 from

http://dokuman.osym.gov.tr/pdfdokuman/2016/KPSS/OABT/OABT

SonucSayisalBilgiler02092016.pdf

Özmantar, M.F., Bingölbali, E. \& Akkoç, H. (Ed.) (2008). Matematiksel kavram yanılgıları ve çözüm önerileri. Ankara: Pegem Akademi. Santagata, R., \& Guarino, J. (2011). Using video to teach future teachers to learn from teaching. ZDM, 43(1), 133-145. Doi: 10.1007/s11858010-0292-3

Santos, J.R.A. (1999). Cronbach's alpha: A tool for assessing the reliability of scales. Journal of extension, 37(2), 1-5.

Schmidt, H. W., Tatto, M. T., Bankov, K., Blömeke, S., Cedillo, T., Cogan, L., Han, S., Houang, R., Hsieh, F. J., Paine, L., Santillan, M., \& Schwille, J. (2007). The preparation gap: Teacher education for middle school mathematics in six countries. Mathematics Teaching in the 21st Century, Center for Research in Mathematics and Science Education, Michigan State University.

Selden, A. \& Selden, J. (2003). Errors and misconceptions in college level theorem proving. Tennessee Technological University Department 
190 Güler \& Çelik - CK vs. PCK en la Enseñanza del Álgebra

of Mathematics Tech Report No. 2003-3. Retrieved from http://math.tntech.edu/techreports/TR_2003_3.pdf

Shulman, L.S. (1986). Those who understand; Knowledge growth in teaching. Educational Researcher, 15(2), 4-14. Doi:

10.3102/0013189X015002004

Shulman, L.S. (1987). Knowledge and teaching: Foundations of the new reform. Harvard Educational Review, 57 (1), 1-22. Doi:

10.17763/haer.57.1.j463w79r56455411

Stump, S. L. (1999). Secondary mathematics teachers' knowledge of slope. Mathematics Education Research Journal, 11(2), 124-144. Doi: 10.1007/BF03217065

Şahin, Ö., Gökkurt, B., \& Soylu, Y. (2016). Examining prospective mathematics teachers' pedagogical content knowledge on fractions in terms of students' mistakes. International Journal of Mathematical Education in Science and Technology, 47(4), 531-551. Doi: 10.1080/0020739X.2015.1092178

Tatto, A., Teresa, M., Schwille Prof, J., Senk Prof, S., Lawrence, C., Peck Mr, R., \& Rowley Dr, G. (2012). Policy, practice, and readiness to teach primary and secondary mathematics in 17 countries: Findings from the IEA Teacher Education and Development Study in Mathematics (TEDS-M) (pp. 1-297). International Association for the Evaluation of Educational Achievement (IEA).

Tatto, M. T., Schwille, J., Senk, S., Ingvarson, L., Peck, R., \& Rowley, G. (2008). Teacher Education and Development Study in Mathematics (TEDS-M): Conceptual framework. East Lansing, MI: Teacher Education and Development International Study Center, College of Education, Michigan State University.

Taylan, R.D., \& da Ponte, J.P. (2016). Investigating pedagogical content knowledge-in-action. REDIMAT, 5(3), 212-234. doi:

10.4471/redimat.2016.2227

Thompson, P. W. (1994). Students, functions, and the undergraduate curriculum. In E. Dubinsky, A. H. Schoenfeld, and J. J. Kaput (Eds.), Research in Collegiate Mathematics Education, 1 (Issues in Mathematics Education Vol. 4, pp. 21-44). Providence, RI: American Mathematical Society.

Usiskin, Z. (1988). Conceptions of school algebra and uses of variable. In A. F. Coxford and A. P. Shulte (Eds.), The ideas of algebra, K-12 
(1988 Yearbook of the National Council of Teachers of Mathematics, pp. 8-19). Reston, VA: NCTM.

Warburton, R. (2013a) 'Mathematical Knowledge for Teaching': Do you need a mathematics degree? Proceedings of the British Society for Research into Learning Mathematics, 33(2), 61-66.

Watson, J., Kelly, B., \& Izard, J. (2004). Student change in understanding of statistical variation after instruction and after two years: An application of Rasch analysis. AARE Conference, Melbourne, Url: http://www.aare.edu.au (search code WAT04867).

Wolfe, EW, \& Smith Jr, EV. (2007a). Instrument development tools and activities for measure validation using Rasch models: part Iinstrument development tools. Journal of Applied Measurement, $8(1), 97-123$.

Wolfe, EW, \& Smith Jr, EV. (2007b). Instrument development tools and activities for measure validation using Rasch models: part II-validation activities. Journal of Applied Measurement, 8(2), 204-234.

Wright, B. D. (1977). Solving measurement problems with the Rasch model. Journal of Educational Measurement, 14(2), 97 - 116. Doi: 10.1111/j.1745-3984.1977.tb00031.x

Yenilmez, K., \& Avcu, T. (2009). Sixth grade students' success levels on algebra learning domain. Ahi Evran Üniversitesi Eğitim Fakültesi Dergisi, 10(2), 37-45.

Yüksek Öğretim Kurumu [YÖK] (2016). Ilköğretim matematik ögretmenliği lisans programı [Bachelor curriculum of elementary school mathematics education department]. Retrieved from http://www.yok.gov.tr/documents/10279/49665/ ilkogretim_matematik/cca48fad-63d7-4b70-898c-dd2eb7afbaf5

Mustafa Güler is a PhD. candidate at the Karadeniz Technical University, Turkey.

Derya Çelik is associated professor at the Karadeniz Technical University, Turkey.

Contact Address: Direct correspondence concerning this article, should be addressed to the author. Postal address: Karadeniz Technical University, 61300, Trabzon, Turkey. Email: mustafaguler@ktu.edu.tr 
192 Güler \& Çelik-CK vs. PCK en la Enseñanza del Álgebra

\section{Appendix 1}

Expertise form for 15 th question of APCK test

\begin{tabular}{|c|c|c|c|c|c|}
\hline Algebra Content & & PCK & Do & $\begin{array}{l}\text { mains of Mathematica } \\
\text { Knowledge }\end{array}$ & \\
\hline Expressions, equations and inequalities & $\square$ & Knowledge of learner & $\square$ & Core concepts and procedures & $\square$ \\
\hline \multirow[t]{3}{*}{ Functions, their properties: Linear and nonlinear } & $\square$ & Presentation of content & $\square$ & Representations & $\square$ \\
\hline & & & & Applications & $\square$ \\
\hline & & & & Reasoning and proof & $\square$ \\
\hline
\end{tabular}

15. Is it possible to solve the equation $2 x+1=5 x+7$ by drawing pictures of weights and balance scales? If yes, please demonstrate your solution. If not, please explain the reason.

(Adapted from Li, 2007)

\section{Suggestions:}

* The main form was prepared as a booklet. 


\section{Appendix 2}

Reliability analysis of ACK \& APCK tests

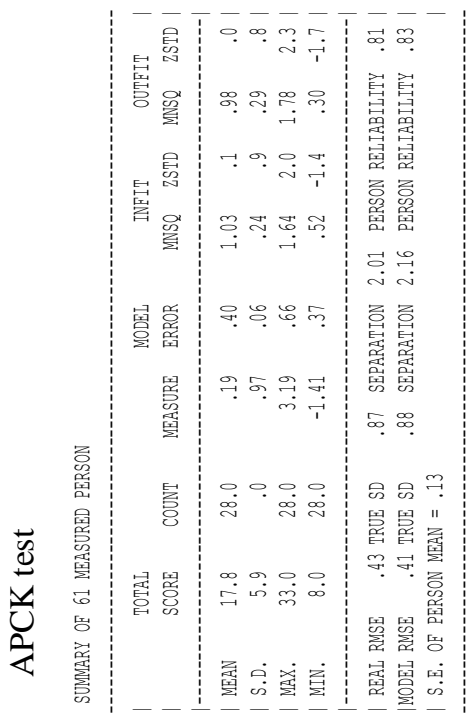

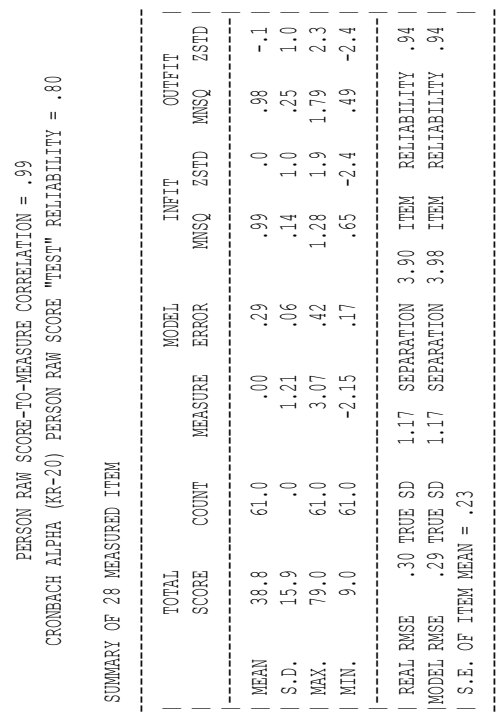
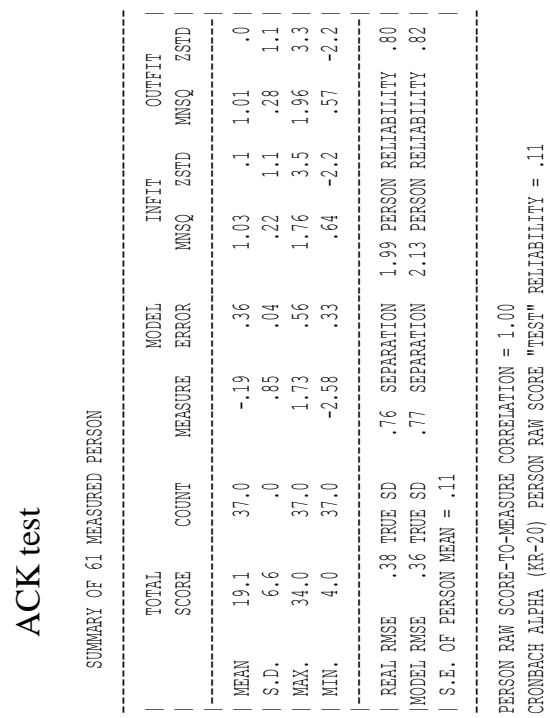

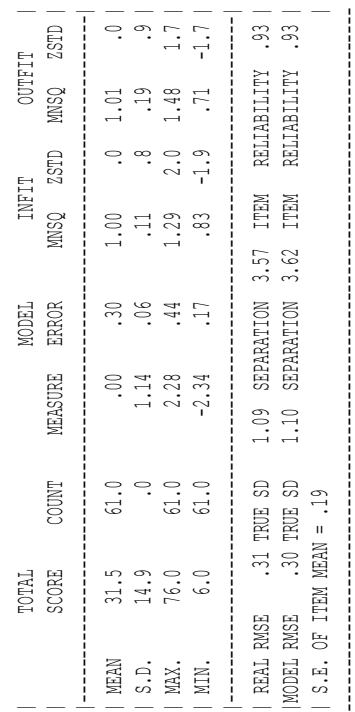




\section{Appendix 3}

Sample test items

\section{Sample questions for APCK test}

10. The teacher Reyhan writes the following inequality on the blackboard and asks her students to find a solution.

$$
-x<7
$$

One of her students, Kubra, divides both sides of the inequality by -1 and writes $x>-7$ for the solution. Then, another student asks the reason why the inequality changed direction. How would you respond to this question? 20.

$\frac{(x+4)}{x+1}=\frac{2 x+8}{3 x}$

A student makes the following explanation and solution for the question given above.

" $(2 x+8)$ is two times $(x+4)$. Then $3 x$ should be two times of $(x+1)$ "

$$
\begin{aligned}
& 2(x+1)=3 x \\
& 2 x+2=3 x \\
& \text { and } 2=x
\end{aligned}
$$

Which of the following is true about this solution?
a) The strategy used by the student is completely wrong.
b) The student made proportion reverse.
c) The result composes the solution set.
d) Although the strategy is true, it gives a missing solution.
e) The student made a calculation error but reached the correct answer by chance.

\section{Sample questions for ACK test}

12. Indicate whether each of the following situations can be modeled by an exponential function.

Yes No

a) The height $h$ of a ball $t$ seconds after it is thrown into the air.

b) The amount of money $A$ in a bank after $w$ weeks, if each week $d$ zeds are put in the bank.

c) The value $V$ of a car after $t$ years if it depreciates $d \%$ per year (Adopted from TEDS-M project, See Tatto et al., 2008)

13. $\mathrm{A}=\left(\begin{array}{ll}p & q \\ r & s\end{array}\right)$ and $\mathrm{B}=\left(\begin{array}{cc}m & n \\ k & l\end{array}\right)$ are two matrixes. Is it true that if $\mathrm{AxB}=0$ then either $\mathrm{A}=0$ or $\mathrm{B}=0$ $(0$, represents the zero matrix)? Justify your answer. 